vation'. This raised over $f 1500$ in support of the Trust. Sir Edmund spoke of problems of conservation and development in Nepal. He emphasised the need for conservation measures in polar environments but believed that Antarctica was still a continent for people and for adventure: he did not wish it to become the sole domain of scientists.
The Antarctic events of the 'New Zealand in Cambridge Week' emphasised the long-standing relationship between Britain and New Zealand in the southern polar regions. It is to be hoped that these links will continue and indeed strengthen, and lead to many more worthwhile cooperative achievements.

\title{
Reviews
}

\section{PICTORIAL ANTARCTICA}

WILD ICE - ANTARCTIC JOURNEYS. Naveen, R., Monteath, C., de Roi, T. and Jones, M. 1990. Washington, Smithsonian Institution. $224 \mathrm{p}$, hard cover, illustrated. ISBN 087474395 8. £19.95, US\$29.50.

Spectacular is the first adjective that springs to mind on an initial browse through this book. It is (and no condescension is intended) primarily a picture book. However, many of the photographs are amongst the best that this reviewer has seen of the Antarctic. This is perhaps not surprising, as all four of the authors are, to a greater or lesser extent, professional photographers. Antarctic wildlife is well represented, with about two thirds of the 150 photographs including a local denizen. Marine phenomena (icebergs, sea ice, etc) are also well represented, as is mountain scenery. However, these represent marginal areas of the Antarctic continent, and it is surprising to find not a single photograph of the vast Antarctic ice sheet, which after all covers over $98 \%$ of the continent. It is arguably not so photogenic, but it and its major outlet glaciers are dominant features of the region.

The book is nominally divided into four sections, one by each of the authors. The text, though unexceptional, is an interesting mix of textbook extracts, philosophy, enthusiasm and conservation gospel. For this reviewer, the most interesting section was that of Colin Monteath, which contains narratives of his journeys with dogs, trips to the Dry Valleys, and researches in the crater of Mount Erebus, together with chilling recollections of recovery operations after the New Zealand DC-10 disaster on Ross Island. For those bound for Antarctica, there is a useful 11-page section on photography in the Antarctic, with recommendations on kit, film etc.

As HRH Prince Edward rightly points out in his foreword, it is virtually impossible to describe the Antarctic accurately to anyone who hasn't been there. Perhaps the chief merit of this book is that it conveys something of the feel of the place. It will thus be of value to those who haven't been there, and will stimulate recollections among those who have. It is well produced and, particularly at the very reasonable price, can be recommended to all interested in images of the Antarctic. (M. R. Gorman, Scott Polar Research Institute, University of Cambridge, Lensfield Road, Cambridge CB2 1ER.)

\section{ANTARCTIC CONSERVATION: THE GREAT DEBATE}

THE FUTURE OF ANTARCTICA: EXPLOITATION VERSUS PRESERVATION. Cook, G. (editor). 1990. Manchester, Manchester University Press. 172 p, soft cover, illustrated. ISBN 071903448 5. £10.95.

This volume is the proceedings of a symposium held at the Sir Robert Menzies Centre for Australian Studies of the Institute of Commonwealth Studies, University of London. The symposium was organized partly in response to the sequellae from the Australian Prime Minister's declining to ratify the Convention on the Regulation of Antarctic Mineral Resource Activities, and also to present general concern about the future of the continent and its resources.

An introduction from the Prime Minister is followed by eight papers that examine various aspects of the subject. Reliability of speculations on the significance of mineral deposits in Antarctica is questioned, and an excellent description is given of the present state of knowledge contrasting sharply with frequent journalistic assertions that certain riches await exploitation in Antarctica. The efficiency of the Antarctic Treaty in controlling activity in the region is assessed, and much common ground appears in otherwise dissenting views. Among the various interests represented, objectives of control and conservation are basically similar, but the methods thought best to achieve them differ widely. Bibliographies accompanying several of the papers are useful sources of the latest expert information on widely discussed subjects. Appendices include texts of the Antarctic Treaty and the Mineral Resources Convention, two documents of primary importance in the debate. The work as a whole is very timely, in view of current negotiations on the exploitation and preservation of Antarctic resources. (R. K. Headland, Scott Polar Research Institute, University of Cambridge, Lensfield Road, Cambridge CB2 1ER.)

\section{A FULL LIFE}

A TIME TO SPEAK: AN AUTOBIOGRAPHY. Fuchs, Sir Vivian. 1990. Oswestry, Anthony Nelson. 310 p, illustrated, hard cover. ISBN 0904614379 . £16.95.

The author is known primarily from his long involvement with Antarctica, which began in 1947 when he took command of the Falkland Islands Dependencies Survey (FIDS), continued with his leadership of the Common- 